\title{
Detection of anti-Neospora caninum antibodies in slaughtered sheep
}

\author{
[Detecção de anticorpos anti-Neospora caninum em ovinos abatidos]
}

\section{"Scientific Article /Artigo Científico"}

\author{
Annelise Castanha Barreto Tenório Nunes ${ }^{1}$, Edna Maria Vieira da Silva² ${ }^{2}$ José Aelson de Oliveira², \\ Pomy de Cássia Peixoto Kim ${ }^{3}$, Jonatas Campos de Almeida ${ }^{1}$, Kleber Barros Nunes ${ }^{4}$, Rafael \\ Antonio Nascimento Ramos ${ }^{5 *}$, Rinaldo Aparecido Mota ${ }^{3}$
}

\author{
${ }^{1}$ Faculdade de Medicina Veterinária, Universidade Federal de Alagoas, Viçosa-AL, Brasil. \\ ${ }^{2}$ Médico-veterinário autônomo, Maceió-AL, Brasil. \\ ${ }^{3}$ Departamento de Medicina Veterinária, Universidade Federal Rural de Pernambuco, Recife-PE, Brasil. \\ ${ }^{4}$ Centro de Controle de Zoonoses, Maceió-AL, Brasil. \\ ${ }^{5}$ Laboratório de Parasitologia, Universidade Federal do Agreste de Pernambuco, Garanhuns-PE, Brasil. \\ *Autor para correspondência/Corresponding author: E-mail: rafael.ramos@ufape.edu.br
}

\begin{abstract}
Neospora caninum is a protozoan that causes reproductive disorders in herbivores. Domestic and wild dogs have been considered its definitive hosts, and when these animals are affected, they may suffer from a neuromuscular disease. Recently, this infection has also gained significance in small ruminants. Although neosporosis is already a proven cause of mortality in lambs and congenital infection can occur, this parasite has only recently been considered a cause of abortion in these animals. The aim of this study was to detect anti- $N$. caninum antibodies in slaughtered sheep. Serum samples $(n=100)$ collected in a slaughterhouse located in the municipality of Palmeira dos Índios $\left(09^{\circ} 24^{\prime} 26^{\prime \prime} \mathrm{S}\right.$ and $\left.36^{\circ} 37^{\prime} 39^{\prime \prime} \mathrm{W}\right)$, state of Alagoas, northeastern Brazil, were used in this study. Anti- $N$. caninum antibodies were detected by means of the Immunofluorescence Antibody Test (IFAT). The cut-off point was set at 50 and samples were titrated up to 800. Anti- $N$. caninum antibodies were detected in $13 \%$ (13/100) of the tested samples, $7.69 \%$ of which came from male sheep (1/13) and $92.31 \%$ (12/13) from females. Titers ranged from 50 to 800, with the majority of animals $(46.15 \%$; 6/13) presenting the maximum one (i.e., 800). Data herein reported demonstrated the circulation of $N$. caninum parasites among sheep in the study area. These findings are pivotal to improve the knowledge about the dynamics of this pathogen in an ovine population. Therefore, it is crucial to adopt sanitary measures to prevent infection by this parasite and thus reduce its economic impact on ovine production.
\end{abstract}

Keywords: neosporosis; small ruminant; Brazil.

\section{Resumo}

Neospora caninum é um protozoário responsável por desordens reprodutivas em herbívoros. Canídeos domésticos e silvestres são considerados os hospedeiros definitivos, e quando acometidos podem apresentar alterações neuromusculares. Recentemente, esta infecção ganhou importância também em pequenos ruminantes, e embora já tenha sido incriminada como causa de mortalidade em cordeiros, este parasito só agora foi relacionado a abortos nestes animais. Objetivou-se neste estudo detectar anticorpos anti- $N$. caninum em ovinos abatidos. Para tanto, amostras de soro $(\mathrm{n}=100)$ foram coletadas em um abatedouro localizado no município de Palmeira dos Índios (09²4’26” S e 36³7’39" O), Alagoas, nordeste do Brasil. Amostras foram testadas através da Reação de Imunofluorescência Indireta (IFI) com o ponto de corte de 50. Todas amostras foram tituladas até 800 . Anticorpos anti- $N$. caninum foram detectados em $13 \%$ (13/100) das amostras testadas, destas 7,69\% foram machos (1/13) e 92,31\% (12/13) fêmeas. Os títulos de anticorpos variaram de 50 a 800 , com a maioria dos animais $(46,15 \%$; 6/13) apresentando a máxima titulação. Dados aqui reportados demonstram a circulação de $N$. caninum nos ovinos da área de estudo. Estes achados são essenciais para melhor entender a dinâmica da disseminação deste patógeno em uma população ovina. 
Portanto, é importante a adoção de medidas sanitárias para prevenir a infecção e reduzir o impacto econômico desta parasitose na população ovina.

Palavras-chave: neosporose; pequenos ruminantes; Brasil.

\section{Introduction}

Neospora caninum (Eucoccidiorida: Sarcocystidae) is an obligate intracellular protozoan considered an important cause of abortion in bovines and of neuromuscular disorders in canids (Cerqueira-Cézar et al., 2017). Domestic and wild canids (coyotes, gray wolves, and Australian dingos) have been considered definitive hosts of this parasite (Cerqueira-Cézar et al., 2017), while herbivores may act as intermediate hosts (Ghalmi et al., 2014).

Transmission to herbivores may occur through the ingestion of sporulated oocysts contained in contaminated food or water (Dubey, 2003). However, it is a known fact today that congenital infection is considered the most important transmission route in herbivores. $N$. caninum infection in these animals is important from an epidemiological point of view, because this protozoan has been considered an important cause of reproductive disorders (Dubey, 2003). For instance, in bovines, N. caninum invades the placenta and induces thrombosis in caruncular vessels, causing fetal vasculitis and several types of fetal brain lesions (Buxton et al., 1998).

Historically, neosporosis has been studied extensively in large ruminants, given that bovines are the most affected species worldwide. However, over the last few years, attention has also focused on small ruminants, including sheep. Although neosporosis is already a proven cause of mortality in lambs and congenital infection can occur, this parasite has only recently been considered a cause of abortion in these animals (Kobayashi et al., 2001; Hässig et al., 2003; Moreno et al., 2012). Indeed, several reports have been published throughout the world highlighting the importance of ovine neosporosis. For example, nowadays, $N$. caninum infection is considered an important cause of abortion in sheep in Spain (Moreno et al., 2012). Moreover, it is important to note that the stage of gestation plays a fundamental role in the course of neosporosis, and is $100 \%$ fatal for the fetus when the infection occurs in the first and second trimesters of pregnancy (Arranz-Solís et al., 2015). The importance of neosporosis in ovine production is indisputable; therefore, the aim of this study was to detect anti- $N$. caninum antibodies in slaughtered sheep.

\section{Material and Methods}

Serum samples from sheep $(\mathrm{n}=100 ; 50$ females and 50 males) used in this study were obtained from a slaughterhouse in the municipality of Palmeira dos Índios $\left(09^{\circ} 24^{\prime} 26^{\prime \prime} \mathrm{S}\right.$ and $36^{\circ} 37^{\prime} 39^{\prime \prime} \mathrm{W}$ ), in the state of Alagoas, northeastern Brazil.

Anti- $N$. caninum antibodies were detected by means of the Immunofluorescence Antibody Test (IFAT). The cut-off point was set at 50 (Acosta et al., 2016) and the procedure was performed as described by Paré et al. (1995). The NC-1 strain of $N$. caninum cultured in bovine monocytes was used as antigen. Positive and negative serum samples were used as controls. Reagent samples were titrated up to 800 .

The resulting data were analyzed based on descriptive statistics to determine values of absolute and relative frequency.

\section{Results and Discussion}

Anti- $N$. caninum antibodies were detected in $13 \%$ of the analyzed samples (13/100), $7.69 \%$ of which were from male sheep (1/13) and $92.31 \%(12 / 13)$ from females. The titers ranged from 50 to 800 , with the majority of animals $(46.15 \% ; 6 / 13)$ presenting the highest one (i.e., $800)$.

This study assessed the frequency of $N$. caninum in slaughtered sheep from a municipality in northeastern Brazil. The infection rate detected (i.e., 13\%) was higher than that reported in a previous study in the same area, where a positivity of $9.6 \%$ was observed (Faria et al., 2010). It is known that the findings of a serological survey can be influenced by various factors, including laboratory procedures (e.g., cut-off point, operator, microscopy). In this study, the influence of these parameters was most likely minimal, since the same group performed the analyses in the same laboratory.

These animals come from a region whose conditions for the survival of oocysts in the 
environment are probably unfavorable, given its hot summers with average temperatures reaching up to $33^{\circ} \mathrm{C}$. In fact, it is still unclear how long sporulated oocysts can survive in the environment (Dubey et al., 2007). Therefore, most likely the congenital transmission played an important role in the infection of animals analyzed in this study, but further analyses are needed to confirm this hypothesis. $N$. caninum has already been reported as a cause of mortality in congenitally infected lambs (Dubey and Lindsay, 1990; Dubey et al., 1990), but so far this protozoan has not been considered the most important infectious cause of abortion in sheep.

Almost all the reactive animals were females $(92.31 \% ; 12 / 13)$. This finding is interesting, suggesting that it may be related with the duration of exposure of the animals to $N$. caninum oocysts in the environment, since females are normally slaughtered when they are older. Little is known about ovine neosporosis prevalence rates in Brazil. Although the data obtained in this study are local, it is important to underscore the presence of this pathogen in sheep flocks in northeastern Brazil. From an epidemiological standpoint, the positivity identified in slaughtered animals is a cause for concern, since part of the carcass of these animals are frequently used to feed dogs (Souza et al., 2019), the definitive host of this protozoan (Dubey, 1999). In fact, it is known that the most common route of transmission to dogs is through the ingestion of raw or undercooked meat containing cysts (Paradies et al., 2007).

Lastly, this study assessed the presence of anti- $N$. caninum antibodies in slaughtered sheep in a region known for congenital infection in this species (Faria et al., 2010). The data reported here are important to improve the knowledge about the dynamics of this pathogen in an ovine population, but several other points remain unclear. In addition, they indicate that small ruminants reared in this region are at risk of infection by this overlooked protozoan parasite. Hence, it is crucial to adopt suitable sanitary measures (e.g., to avoid the presence of dogs together the ovine population, to promote the appropriate discard of placental remains) to prevent infection by this parasite and to reduce its economic impact on ovine production.

\section{Conflict of Interest}

The authors declare that there is no conflict of interest.

\section{References}

Acosta, I.D.; Centoducatte, L.D.; Soares, H.A.; Marcili, A.; Gondim, M.F.; Rossi, J.L.; Gennari, S.M. Occurrence of Neospora caninum and Toxoplasma gondii antibodies in dogs from rural properties surrounding a biological reserve, Espírito Santo, Brazil. Brazilian Journal of Veterinary Parasitology, 25(4): 536-539, 2016.

Arranz-Solís, D.; Benavides, J.; Regidor-Cerrillo, J.; Fuertes, M.; Ferre, I.; Ferreras, M.C.; Collantes-Fernández, E.; Hemphill, A.; Pérez, V.; Ortega-Mora, L.M. Influence of the gestational stage on the clinical course, lesional development and parasite distribution in experimental ovine neosporosis. Veterinary Research, 3(46): 1-13, 2015.

Buxton, D.; Maley, S.W.; Wright, S.; Thomson, K.M.; Rae, A.G.; Innes, E.A. The pathogenesis of experimental neosporosis in pregnant sheep. Journal of Comparative Pathology, 118(4): 267-279, 1998.

Cerqueira-Cézar, C.K.; Calero-Bernal, R.; Dubey, J.P.; Gennari, S.M. All about neosporosis in Brazil. Brazilian Journal of Veterinary Parasitology, 26(3): 253-279, 2017.

Dubey, J.P.; Hartley, W.J.; Lindsay, D.S.; Topper, M.J. Fatal congenital Neospora caninum infection in a lamb. Journal of Parasitology, 76(1): 127-130, 1990.

Dubey, J.P.; Lindsay, D.S. Neospora caninum induced abortion in sheep. Journal of Veterinary Diagnostic Investigation, 2(1): 230-233, 1990.

Dubey, J.P. Recent advances in Neospora and neosporosis. Veterinary Parasitology, 84(34): 349-367, 1999.

Dubey, J.P. Review of Neospora caninum and neosporosis in animals. Korean Journal of Parasitology, 41(1): 1-16, 2003.

Dubey, J.P.; Schares, G.; Ortega-Mora, L.M. Epidemiology and control of neosporosis and Neospora caninum. Clinical Microbiology Review, 20(2): 323-367, 2007.

Faria, E.B.; Cavalcanti, E.F.; Medeiros, E.S.; Pinheiro Jr., J.W.; Azevedo, S.S.; Athayde, A.C.; Mota, R.A. Risk factors associated with Neospora caninum seropositivity in sheep from the state of Alagoas, in the Northeast region of Brazil. Journal of Parasitology, 96(1): 197-199, 2010. 
Ghalmi, F.; China, B.; Jenkins, M.; Azzag, N.; Losson, B. Comparison of different serological methods to detect antibodies specific to Neospora caninum in bovine and canine sera. Journal of Veterinary Diagnostic Investigation, 26(1): 136-140, 2014.

Hässig, M.; Sager, H.; Reitt, K.; Ziegler, D.; Strabel, D.; Gottstein, B. Neospora caninum in sheep: a herd case report. Veterinary Parasitology, 117(3): 213-220, 2003.

Kobayashi, Y.; Yamada, M.; Omata, Y.; Koyama, T.; Saito, A.; Matsuda, T.; Okuyama, K.; Fujimoto, S.; Furuoka, H.; Matsui, T. Naturally-occurring Neospora caninum infection in an adult sheep and her twin fetuses. Journal of Parasitology, 879(2): 434436, 2001.

Moreno, B.; Collantes-Fernández, E.; Villa, A.; Navarro, A.; Regidor-Cerrillo, J.; OrtegaMora, L.M. Occurrence of Neospora caninum and Toxoplasma gondii infections in ovine and caprine abortions. Veterinary Parasitology, 187(1-2): 312-318, 2012.

Paradies, P.; Capelli, G.; Testini, G.; Cantacessi, C.; Trees, A.J.; Otranto, D. Risk factors for canine neosporosis in farm and kennel dogs in Southern Italy. Veterinary Parasitology, 145(3-4): 240-244, 2007.

Paré, J.; Hietala, S.K.; Thurmond, M.C. Interpretation of an indirect fluorescent antibody test for diagnosis of Neospora sp. infection in cattle. Journal of Veterinary Diagnostic Investigation, 7(1): 273-275, 1995.

Souza, I.B.; Fernandes, P.R.; Silva, T.R.M.; Santos, C.V.B.; Silva, N.M.M.D.; UbirajaraFilho, C.R.C.; Carvalho, G.A.; Alves, L.C.; Mota, R.A.; Ramos, R.A.N. Seroprevalence of Neospora caninum and Toxoplasma gondii in dogs from an urban area of North-eastern Brazil: a spatial approach. Revista da Sociedade Brasileira de Medicina Tropical, 52: e20180440, 2019. 